\title{
Methionine Sulfoxide Reductases Protect against Oxidative Stress in Staphylococcus aureus Encountering Exogenous Oxidants and Human Neutrophils
}

\author{
Yun Yun Pang a Jamie Schwartz ${ }^{\text {a }}$ Sarah Bloomberg ${ }^{\text {a }}$ Jeffrey M. Boyd ${ }^{d}$ \\ Alexander R. Horswill ${ }^{b}$ William M. Nauseef ${ }^{a-c}$ \\ ${ }^{a}$ Inflammation Program, Department of Medicine, and ${ }^{b}$ Department of Microbiology, Roy J. and Lucille A. Carver \\ College of Medicine, University of lowa, and 'Veterans Administration Medical Center, lowa City, lowa, and \\ ${ }^{\mathrm{d}}$ Department of Biochemistry and Microbiology, Rutgers University, New Brunswick, N.J., USA
}

\section{Key Words}

Methionine sulfoxide reductase $\cdot$ Staphylococcus aureus .

Neutrophils · Oxidative stress

\begin{abstract}
To establish infection successfully, Staphylococcus aureus must evade clearance by polymorphonuclear neutrophils (PMN). We studied the expression and regulation of the methionine sulfoxide reductases (Msr) that are involved in the repair of oxidized staphylococcal proteins and investigated their influence on the fate of $S$. aureus exposed to oxidants or PMN. We evaluated a mutant deficient in $m s r A 1$ and $m s r B$ for susceptibility to hydrogen peroxide, hypochlorous acid and $\mathrm{PMN}$. The expression of $\mathrm{ms} A \mathrm{~A} 1$ in wild-type bacteria ingested by human PMN was assessed by real-time PCR. The regulation of $m s r$ was studied by screening a library of two-component regulatory system (TCS) mutants for altered msr responses. Relative to the wild-type bacteria, bacteria deficient in Msr were more susceptible to oxidants and PMN. Upregulation of staphylococcal msrA1 occurred within the phagosomes of normal PMN and PMN deficient in NADPH oxidase activity. Furthermore, PMN granule-rich extract stimulated the upregulation of msrA1. Modulation of msrA1 within PMN was shown to be partly dependent on the VraSR TCS. Msr contributes to
\end{abstract}

staphylococcal responses to oxidative attack and PMN. Our study highlights a novel interaction between the oxidative protein repair pathway and the VraSR TCS that is involved in cell wall homeostasis.

(c) 2013 S. Karger AG, Basel

\section{Introduction}

Staphylococcus aureus is an important human pathogen that is responsible for a broad spectrum of infections, ranging from mild cellulitis to life-threatening endovascular disease. The rising prevalence of antibiotic resistance among staphylococci exacerbates the clinical challenges imposed by staphylococcal disease.

Optimal host defense relies on the capacity of polymorphonuclear neutrophils (PMN) to phagocytose and kill $S$. aureus with antimicrobial agents delivered to or generated in phagosomes. Especially potent among phagosomal oxidants is hypochlorous acid $(\mathrm{HOCl})$, which is generated by the myeloperoxidase-hydrogen peroxide (MPO$\mathrm{H}_{2} \mathrm{O}_{2}$ )-chloride system [1]. PMN-derived oxidants readily damage bacterial proteins, lipids and DNA. Methionine is

Y.Y.P. and J.S. contributed equally to this article.

\section{KARGER}

E-Mail karger@karger.com

www.karger.com/jin
(C) 2013 S. Karger AG, Basel

$1662-811 X / 13 / 0063-0353 \$ 38.00 / 0$
Dr. William M. Nauseef

Inflammation Program and Department of Medicine

Roy J. and Lucille A. Carver College of Medicine, University of Iowa

D160 MTF, 2501 Crosspark Road, Coralville, IA 52241 (USA)

E-Mail william-nauseef@uiowa.edu 
Table 1. S. aureus strains and plasmids used in this study

\begin{tabular}{|c|c|c|c|c|}
\hline Wild-type & USA300-0114 MRSA $\triangle$ pUSA03 & & $\mathrm{erm}^{\mathrm{s}}$ & {$[7]$} \\
\hline Wild-type pCM 28 & USA300-0114 MRSA $\triangle$ pUSA03 & pCM28 & $\mathrm{erm}^{\mathrm{s}} \mathrm{Cm}^{\mathrm{r}}$ & this study \\
\hline$\triangle m s r A 1 B$ & USA300-0114 MRSA $\triangle$ pUSA03 & & $\mathrm{erm}^{\mathrm{s}}$ & this study \\
\hline$\triangle m s r A 1 B$ pCM 28 & USA300-0114 MRSA $\triangle$ pUSA03 & pCM28 & $\mathrm{erm}^{\mathrm{s}}$ & this study \\
\hline$\triangle m s r A 1 B$ pCM $28-m s r A 1 B$ & USA300-0114 MRSA $\triangle$ pUSA03 & pCM28-msrA1B & $\mathrm{erm}^{\mathrm{s}} \mathrm{Cm}^{\mathrm{r}}$ & this study \\
\hline$\Delta$ nre & USA300-0114 MRSA $\triangle$ pUSA03 & SAUSA300_2337-38 & $\mathrm{erm}^{\mathrm{s}}$ & this study \\
\hline$\Delta 0217-8$ & USA300-0114 MRSA $\triangle$ pUSA03 & SAUSA300_0217-18D & $\mathrm{erm}^{\mathrm{s}}$ & this study \\
\hline$\Delta 1219-20$ & USA300-0114 MRSA $\triangle$ pUSA03 & SAUSA300_1219-20 & $\mathrm{erm}^{\mathrm{s}}$ & this study \\
\hline$\Delta k d p$ & USA300-0114 MRSA $\triangle$ pUSA03 & SAUSA300_2035-36 & $\mathrm{erm}^{\mathrm{s}}$ & this study \\
\hline$\Delta 2558-9$ & USA300-0114 MRSA $\triangle$ pUSA03 & SAUSA300_2558-59A & $\mathrm{erm}^{\mathrm{s}}$ & this study \\
\hline$\Delta 1798-9$ & USA300-0114 MRSA $\triangle$ pUSA03 & SAUSA300_1798-99A & $\mathrm{erm}^{\mathrm{s}}$ & this study \\
\hline$\Delta a r l$ & USA300-0114 MRSA $\triangle$ pUSA03 & SAUSA300_1307-08 & $\mathrm{erm}^{\mathrm{s}}$ & this study \\
\hline$\Delta 1441-2$ & USA300-0114 MRSA $\triangle$ pUSA03 & SAUSA300_1441-42 & $\mathrm{erm}^{\mathrm{s}}$ & this study \\
\hline$\Delta a g r$ & USA300-0114 MRSA $\triangle$ pUSA03 & $\Delta a g r::$ tetM & tet $^{\mathrm{r}}$ & {$[8]$} \\
\hline sae::spec & USA300-0114 MRSA $\triangle$ pUSA03 & sae::spec & $\operatorname{spec}^{r}$ & {$[9]$} \\
\hline graS::Tn-mariner & USA300-0114 MRSA $\triangle$ pUSA03 & graS::Tn-mariner & $\mathrm{erm}^{\mathrm{r}}$ & \\
\hline pCM28 & & empty & $\mathrm{amp}^{\mathrm{r}} \mathrm{Cm}^{\mathrm{r}}$ & {$[11]$} \\
\hline pEPSA5 & & empty & $\operatorname{amp}^{r} \mathrm{Cm}^{\mathrm{r}}$ & {$[12]$} \\
\hline pCM28-msrA1B & & pCM28-msrA1B & $\mathrm{amp}^{\mathrm{r}} \mathrm{Cm}^{\mathrm{r}}$ & this study \\
\hline pEPSA5-vraSR & & pEPSA5-vraSR & $\mathrm{amp}^{\mathrm{r}} \mathrm{Cm}^{\mathrm{r}}$ & this study \\
\hline pJB38 & & & $\mathrm{amp}^{\mathrm{r}} \mathrm{Cm}^{\mathrm{r}}$ & {$[10]$} \\
\hline pJMB176 & & pJB38 $\Delta m s r A 1 B$ & $\mathrm{amp}^{\mathrm{r}} \mathrm{Cm}^{\mathrm{r}}$ & this study \\
\hline pJB204 & & pJB38 $\Delta v r a S R$ & $\mathrm{amp}^{\mathrm{r}} \mathrm{Cm}^{\mathrm{r}}$ & this study \\
\hline
\end{tabular}

For antibiotic sensitivity to ampicillin, erythromycin, spectinomycin and chloramphenicol: ${ }^{\mathrm{s}}=$ sensitive; $^{\mathrm{r}}=\mathrm{resistant}^{\text {. }}$

highly susceptible to oxidation, and oxidation in proteins can disrupt their normal function [2]. Methionine can be oxidized to either of two enantiomers, methionine-S-sulfoxide and methionine-R-sulfoxide, and each can be selectively repaired by a specific class of methionine sulfoxide reductase (Msr); MsrA and MsrB repair the S and R stereoisomers, respectively. The $S$. aureus genome harbors three $m s r A$ genes ( $m s r A 1, m s r A 2$ and $m s r A 3)$ and a single $m s r B$ [3]. The adjacent $m s r A 1$ and $m s r B$ genes are cotranscribed and encode enzymes that provide the majority of the Msr activity in S. aureus [4, 5].

To persist and subsequently establish infection, invading bacteria need to evade, resist or tolerate insults inflicted by PMN. Given the role of Msr in the defense against physiological oxidative stress [6], we speculated that $S$. aureus might employ these enzymes to repair and thus limit damage caused by PMN-derived oxidants, thereby providing a mechanism to survive within phagosomes.
In this study, we investigated the contribution of Msr to the fate of $S$. aureus exposed to oxidants and to human $\mathrm{PMN}$. We also explored the regulation of $m s \mathrm{r}$ in $S$. aureus ingested by PMN and the role of staphylococcal twocomponent regulatory systems (TCS) in regulating the $m s r A 1$ response.

\section{Methods}

\section{Bacterial Strains and Culture Conditions}

The $S$. aureus strains used in this study were constructed in the community-associated $S$. aureus USA300 LAC strain that is cured of the native plasmid pUSA03 which confers erythromycin resistance [7] unless otherwise indicated. S. aureus was cultured in tryptic soy broth (TSB; BD Biosciences) at $37^{\circ} \mathrm{C}$ with shaking at $200 \mathrm{rpm}$. For strains harboring empty vector or complementation plasmids, the media was supplemented with $10 \mu \mathrm{g} / \mathrm{ml}$ of chloramphenicol (Sigma-Aldrich; table 1). To obtain stationary phase organisms, bacteria were inoculated from glycerol stocks into TSB 
Table 2. Oligonucleotides used in this study

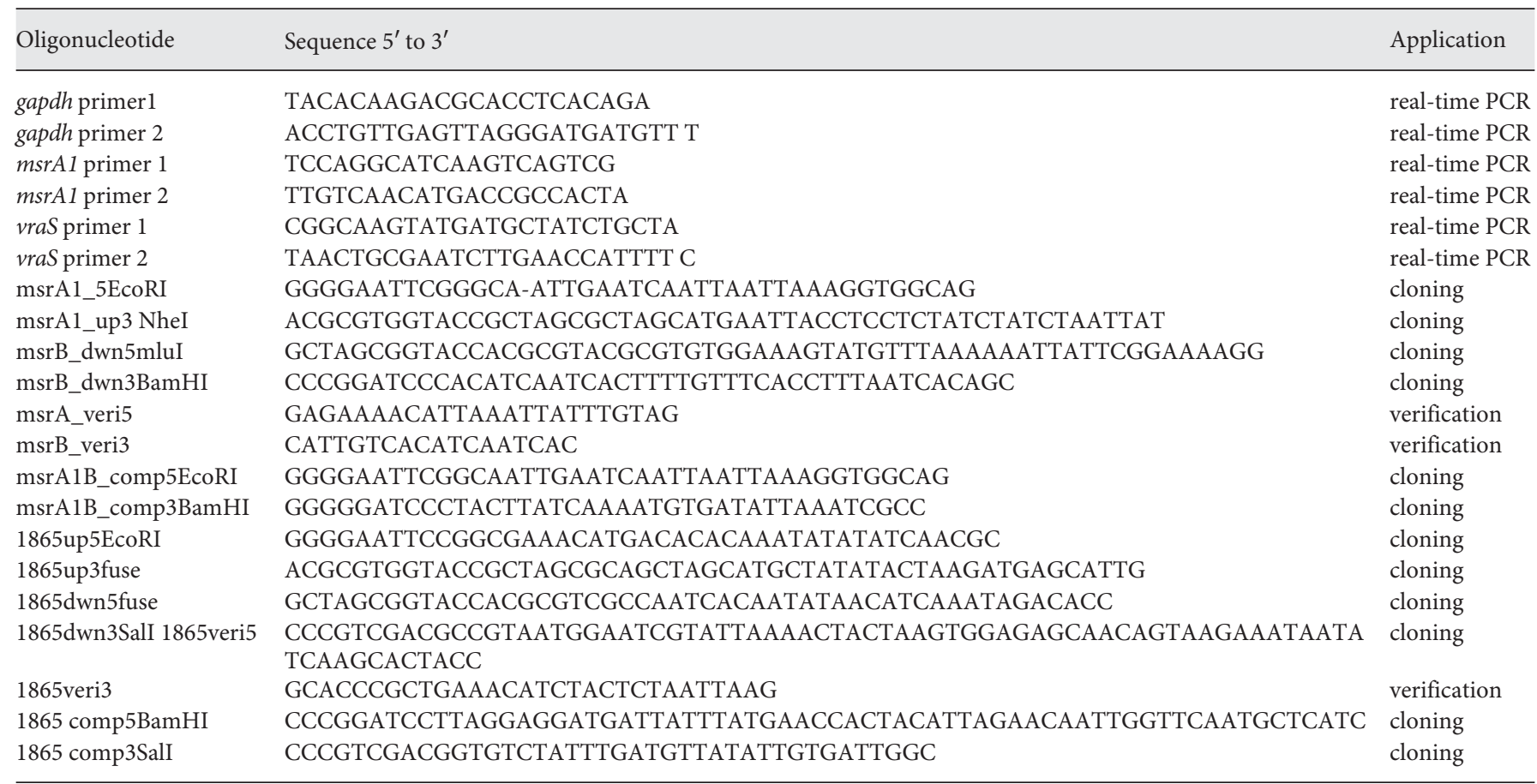

and grown for 16-18 h. For mid-log phase bacteria, the stationary bacteria were subcultured for approximately $2.5 \mathrm{~h}$ from a starting optical density at $550 \mathrm{~nm}\left(\mathrm{OD}_{550}\right)$ of 0.05 . In experiments involving PMN, $0.01 \%$ of human serum albumin (Talecris Biotherapeutics) was added to the subculture media. For experiments measuring $m s r A 1$ expression in the presence of both oxidants and vancomycin, an overnight starter culture of $S$. aureus grown in TSB was washed once with HEPES-buffered Hank's balanced salt solution (HBSS) before being used to innoculate minimal media $(7.6 \mathrm{mM}$ $\mathrm{NH}_{4} \mathrm{SO}_{4}, 33 \mathrm{mM} \mathrm{KH}{ }_{2} \mathrm{PO}_{4}, 60 \mathrm{mM} \mathrm{K}_{2} \mathrm{HPO}_{4}, 11 \mathrm{mM} \mathrm{NaCl}, 3 \mathrm{~mm}$ $\mathrm{KCl}, 0.2 \%$ glucose, $1 \mathrm{mM} \mathrm{MgSO} 4,0.5 \mu \mathrm{g} / \mathrm{ml}$ nicotin, $0.5 \mu \mathrm{g} / \mathrm{ml}$ thiamine, $0.5 \mu \mathrm{g} / \mathrm{ml}$ panthothenate, $3 \mathrm{ng} / \mathrm{ml}$ biotin, and $25 \mu \mathrm{g} / \mathrm{ml}$ of each of the following amino acids: Gly, Val, Leu, Thr, Phe, Tyr, Cys, Met, Pro, Arg, and His). The bacteria were then cultured between 4 and 6 h before being treated.

Construction of $\triangle m s r A 1 B, \Delta v r a S R$ and TCS Mutants

S. aureus strains with mutations in the graRS [7], agr [8] and saeRS [9]. TCS were available as part of laboratory collections (table 1). Other TCS chromosomal mutations, $\triangle m s r A 1 B$ and $\triangle v r a S R$ strains were created by homologous recombination using pJB38 [10]. To create the complementing plasmid and strains, the $m s r A 1$ and $m s r B$ or $v r a S R$ genes were amplified by PCR and cloned into the multicopy plasmids pCM28 [11] or pEPSA5 [12]. All clones were passaged through RN4220 [13] and subsequently transduced into the appropriate strains using bacteriophage $80 \alpha$ [14]. For oligonucleotide (Integrated DNA Technologies) sequences, refer to table 2. See online supplementary information for further details (for all online suppl. material, see www.karger. com/doi/10.1159/000355915).

Methionine Sulfoxide Reductases in

S. aureus

\section{Neutrophil Isolation}

Informed consent was obtained from each individual following a protocol approved by the institutional review board for human subjects at the University of Iowa. Peripheral blood was drawn from normal healthy volunteers or individuals with X-linked chronic granulomatous disease (CGD), and PMN were purified as previously described [15].

\section{Feeding PMN to S. aureus and PMN Killing Assay}

Mid-log phase bacteria were pelleted for $5 \mathrm{~min}$ and resuspended in $20 \mathrm{mM}$ HEPES-buffered HBSS containing $\mathrm{Ca}^{2+}$ and $\mathrm{Mg}^{2+}$. The $\mathrm{OD}_{550}$ of the suspension was measured and this was converted to colony-forming units $(\mathrm{CFU}) /$ milliliter: an $\mathrm{OD}_{550}$ reading of 1.0 was equivalent to $3 \times 10^{8} \mathrm{CFU} / \mathrm{ml}$. Bacteria were used immediately or held on ice. Bacteria were opsonized by incubation at $37^{\circ} \mathrm{C}$ for $20 \mathrm{~min}$ in the presence of $10 \%$ pooled human serum. Opsonized bacteria were fed to PMN or PMN pretreated with $10 \mu \mathrm{M}$ diphenylene iodonium (DPI) at the desired multiplicity of infection (MOI) and tumbled end over end at $37^{\circ} \mathrm{C}$ to allow phagocytosis to proceed. The PMN were then pelleted at $380 \mathrm{~g}$ for $5 \mathrm{~min}$, and the extracellular bacteria were aspirated away. The cell pellets were resuspended to the original volume with $20 \mathrm{mM} \mathrm{HEPES}$-buffered HBSS. These samples were processed to quantitate CFU to assess PMN-mediated killing or prepared for gene expression experiments. For PMN killing experiments, a $50-\mu \mathrm{l}$ sample of cell suspension was removed at the $0 \mathrm{~min}$ (time 0 ). The remaining samples were tumbled at $37^{\circ} \mathrm{C}$, and $50-\mu$ laliquots were removed at specified time points. For viability testing, the $50-\mu \mathrm{l}$ samples were diluted and incubated with $2.5 \mathrm{ml}$ of $\mathrm{pH} 11$ water for $5 \mathrm{~min}$ to lyse the PMN. These samples were vortexed and serially diluted 
into saline. $10 \mu \mathrm{l}$ of each diluted sample was spotted onto tryptic soy agar plates in at least triplicate. After $16 \mathrm{~h}$ of growth at $37^{\circ} \mathrm{C}$, the CFU were enumerated. From these, the CFU in the total PMN suspension for each sample were calculated. To assess the viability at each time point, the total calculated $\mathrm{CFU}$ for each strain were expressed as a percentage of the starting CFU for that strain. The starting CFU for each strain were taken as the CFU recovered from bacteria fed to DPI-treated PMN at time 0 , in which there was minimal bacterial killing (data not shown). For gene expression experiments, the samples were tumbled at $37^{\circ} \mathrm{C}$ and at the desired time point, and the PMN that had ingested bacteria were pelleted, lysed and processed for real-time PCR analysis.

\section{Real-Time PCR}

RNA was extracted from bacteria or PMN-ingested bacteria as described previously [11]. cDNA was synthesized with AMV Reverse Transcriptase (Roche) and used as a template for real-time PCR. Reactions were conducted in PerfeCTa SYBR Green fast mix ROX (Quanta Biosciences) with each primer at $200 \mathrm{nM}$. Expression of gapdh was used to normalize all the gene expression data as described previously [11]. The gapdh primers amplify S. aureus gap$d h$ but do not amplify human gapdh (data not shown). After denaturation at $95^{\circ} \mathrm{C}$ for $30 \mathrm{~s}$, the samples were cycled at $95^{\circ} \mathrm{C}$ for $15 \mathrm{~s}$, then at $60^{\circ} \mathrm{C}$ for $30 \mathrm{~s}$, for 40 cycles using the ABI 7000 system. For primer sequences, refer to table 2 .

\section{Bacterial Exposure to Oxidants}

In experiments used to determine the susceptibility of bacteria to oxidants, $S$. aureus strains in the mid-log phase were resuspended in PBS to an $\mathrm{OD}_{550}$ of 0.250 . Bacteria (0.5 ml volume) were either left untreated or treated with reagent grade $\mathrm{H}_{2} \mathrm{O}_{2}$ or $\mathrm{HOCl}$ (Sigma-Aldrich) at predetermined concentrations for $1 \mathrm{~h}$ at $37^{\circ} \mathrm{C}$. Residual $\mathrm{H}_{2} \mathrm{O}_{2}$ was quenched by diluting samples $1: 100$ in PBS supplemented with catalase $(1,300 \mathrm{U} / \mathrm{ml}$; Sigma). Where $\mathrm{H}_{2} \mathrm{O}_{2}$-MPO was employed, $75 \mathrm{nmol} \mathrm{H}_{2} \mathrm{O}_{2}$ was added to each 0.75 -ml sample with $0,1.5,3.8,7.5$ or 15 pmol of recombinant MPO. In parallel, samples without $S$. aureus were assayed for HOCl generation $(n=3)$, as described in Dypbukt et al. [16]. The average amount of $\mathrm{HOCl}$ generated from 3 experiments was used to plot the data. After the 1-hour incubation, samples were diluted and spot-plated onto tryptic soy agar (BD Biosciences). $\mathrm{CFU}$ for each strain were enumerated after overnight growth at $37^{\circ} \mathrm{C}$ and then calculated as a percentage of non-treated bacteria for the same strain at time 0 . For gene expression studies, $S$. aureus was resuspended to an $\mathrm{OD}_{550}$ of 0.25 in minimal media before being challenged with $\mathrm{H}_{2} \mathrm{O}_{2}$ or $\mathrm{HOCl}$ at the specified concentrations in the presence or absence of $7 \mu \mathrm{g} / \mathrm{ml}$ of vancomycin for $1 \mathrm{~h}$ at $37^{\circ} \mathrm{C}$.

\section{Bacterial Exposure to PMN Granule-Rich Extract}

PMN were resuspended in cold relaxation buffer (RB; $10 \mathrm{mM}$ PIPES, pH 7.3, $100 \mathrm{mM} \mathrm{KCl,} 3 \mathrm{mM} \mathrm{NaCl}_{2}, 3.5 \mathrm{mM} \mathrm{MgCl}_{2}, 1.25 \mathrm{mM}$ EGTA, 1 mM ATP) and sonicated on ice. Unbroken cells and nuclei were pelleted $\left(200 \mathrm{~g}\right.$ at $4^{\circ} \mathrm{C}$ for $5 \mathrm{~min}$ ) and the supernatant was centrifuged at $10,000 \mathrm{~g}$ at $4^{\circ} \mathrm{C}$ for $20 \mathrm{~min}$. The granule-enriched pellet was washed with ice-cold RB, spun at $10,000 \mathrm{~g}$, resuspended in $\mathrm{RB}$ and lysed by freeze thawing 3 times in a methanol-dry ice bath. Granule proteins $\left(10^{7}\right.$ cell equivalents) and $1.5 \times 10^{8}$ bacteria were incubated together in HBSS with calcium and magnesium for $30 \mathrm{~min}$ at $37^{\circ} \mathrm{C}$.

\section{Treatment with Cell Wall-Active Antibiotics}

In experiments involving TCS mutants, $S$. aureus were diluted to an $\mathrm{OD}_{550}$ of 0.3 in TSB, in the presence or absence of $7 \mu \mathrm{g} / \mathrm{ml}$ of vancomycin or $25 \mu \mathrm{g} / \mathrm{ml}$ of D-cycloserine (Sigma-Aldrich), and shaken at $200 \mathrm{rpm}$ for $1 \mathrm{~h}$ at $37^{\circ} \mathrm{C}$.

\section{Msr Activity Assay}

Bacteria were washed with assay buffer (50 mM TRIS- $\mathrm{HCl}$, $\mathrm{pH} 7.5,145 \mathrm{~mm} \mathrm{NaCl}$ ), pelleted and resuspended into $200 \mu \mathrm{l}$ of assay buffer. Bacteria were lysed with $25 \mu \mathrm{g}$ of lysostaphin (Sigma-Aldrich) at $37^{\circ} \mathrm{C}$ for $10 \mathrm{~min}$. Lysates were sonicated on ice and then incubated with $2 \mathrm{mM}$ dabsyl-methionine sulfoxide (a mixture of the S and R enantiomers; Anaspec) and $20 \mathrm{mM}$ DTT in assay buffer. After $1 \mathrm{~h}$ at $37^{\circ} \mathrm{C}$, reactions were quenched with acetonitrile. Samples were analyzed on an LC-Dabs HPLC column (Supelco) to separate dabsyl-methionine sulfoxide from dabsyl-methionine. For further details, refer to the online supplementary material.

\section{Statistical Analysis}

Statistical analyses were performed using Graphpad Prism 5 software. Data were analyzed using paired t tests or one-way ANOVA with post-tests as indicated in the figure legends. $p$ values $<0.05$ were considered to be statistically significant.

\section{Results}

\section{Validation of the msrA1 msrB Deletion Mutant}

To study the role of Msr in S. aureus, we created a mutant in the wild-type background in which both the $m s r A 1$ and $m s r B$ genes were deleted $(\triangle m s r A 1 B)$. The growth of the $\triangle m s r A 1 B$ double-mutant strain was indistinguishable from that of the parent strain (online suppl. fig. 1).

To assess the impact of $m s r A 1 B$ deletion on Msr activity in $S$. aureus, we studied bacteria in the absence or presence of vancomycin, since Msr expression increases upon exposure to cell wall antibiotics such as vancomycin [17]. In the absence of vancomycin, Msr activity in the wildtype lysates was low, and in $\triangle m s r A 1 B$, it was below the level of detection (fig. 1). Msr activity was restored when both $m s r A 1$ and $m s r B$ were reintroduced into the $\triangle m s r A 1 B$ strain via a multicopy plasmid (pCM28). Upon treatment with vancomycin, Msr activity increased in the wild-type and the complemented deletion mutant $(\triangle m s r A 1 B$ with pCM28-msrA $1 B$ ), but not in $\triangle m s r A 1 B$. Thus, the data confirm that under these conditions, MsrA1 and MsrB support the majority of Msr activity in S. aureus, which was eliminated in our $m s r A 1 B$ deletion mutant.

\section{Susceptibility of Wild-Type and msr Mutants to Oxidants and PMN}

Reasoning that the capacity to repair oxidant-mediated damage by Msr would provide a survival advantage, we 


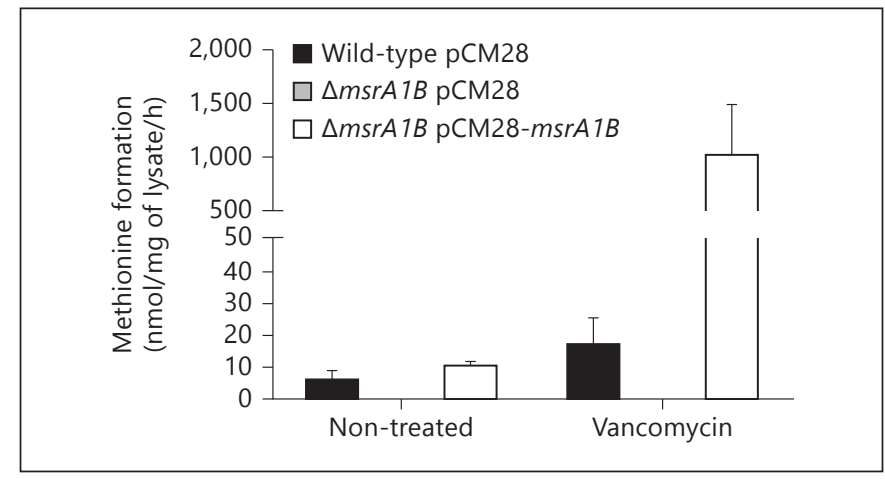

Fig. 1. Msr activity in wild-type and msr mutants. Conversion of dabsyl-methionine sulfoxide to dabsyl-methionine by lysates from wild-type, $\triangle m s r A 1 B$ and complemented $\triangle m s r A 1 B$ mutants were measured. Bacteria were treated with buffer (non-treated) or with vancomycin for $1 \mathrm{~h}$. Data represent the mean \pm SEM $(n=3$ experiments).

compared the abilities of the wild-type, $\triangle m s r A 1 B$ and complemented mutant strains to grow after exposure to $\mathrm{H}_{2} \mathrm{O}_{2}$ for $1 \mathrm{~h}$ in PBS. The number of culturable bacteria present after treatment with $\mathrm{H}_{2} \mathrm{O}_{2}$ was expressed as a percentage of the initial number of bacteria present prior to treatment.

At the lowest concentration of $\mathrm{H}_{2} \mathrm{O}_{2}$ tested $(25 \mathrm{mM})$, there was no significant difference in the growth of the wild-type or $\triangle m s r A 1 B$ mutant after exposure to the oxidant. At higher concentrations of $\mathrm{H}_{2} \mathrm{O}_{2}$ (50, 75 and $100 \mathrm{mM}$ ), the viability of the wild-type mutant was greater than that of $\triangle m s r A 1 B$ mutant ( $p<0.05$; fig. $2 \mathrm{a}$ ). Viability of the complemented mutant treated with $25-75 \mathrm{mM}$ of $\mathrm{H}_{2} \mathrm{O}_{2}$ was likewise better than that of the $\triangle m s r A 1 B$ strain, suggesting that $m s r A 1 B$ contributed to better survival of bacteria in the presence of $\mathrm{H}_{2} \mathrm{O}_{2}$ at these concentrations. At $100 \mathrm{mM} \mathrm{H}_{2} \mathrm{O}_{2}, \Delta m s r A 1 B$ and its complement were equally susceptible to killing by $\mathrm{H}_{2} \mathrm{O}_{2}$, suggesting that expression of $m s r A 1 B$ driven from the complementation plasmid where gene dosage is not precisely controlled may be limited.

Although $\mathrm{H}_{2} \mathrm{O}_{2}$ contributes to oxidative stress imposed on bacteria within PMN phagosomes, most of the oxygen consumed by activated PMN is converted into HOCl [18-20], a more potent antimicrobial agent [21]. To determine whether Msr-deficient S. aureus was more vulnerable to damage by the physiologically relevant oxidant $\mathrm{HOCl}$, we subjected $S$. aureus to sublethal amounts of $\mathrm{HOCl}$ or a $\mathrm{HOCl}$-generating system $\left(\mathrm{MPO}-\mathrm{H}_{2} \mathrm{O}_{2}-\right.$ chloride). The latter system generates toxic oxidants continuously and better mirrors conditions that exist within PMN phagosomes.

Methionine Sulfoxide Reductases in S. aureus
The number of bacteria recovered after treatment with $\mathrm{HOCl}$ was expressed as a percentage of the initial number of bacteria prior to treatment (fig. 2b). Wild-type bacteria were more resistant to killing by $100 \mu \mathrm{M} \mathrm{HOCl}$ than was $\triangle m s r A 1 B(\mathrm{p}<0.01$; fig. $2 \mathrm{~b})$. In the presence of the $\mathrm{HOCl}-$ generating system, the wild-type and $\triangle m s r A 1 B$ strains also exhibited a significant difference in survival at the high end of concentrations of $\mathrm{HOCl}$ produced $(\mathrm{p}<0.05$; fig. 2c).

Given that Msr can influence the susceptibility of wildtype $S$. aureus to the antimicrobial effects of $\mathrm{H}_{2} \mathrm{O}_{2}$ and $\mathrm{HOCl}$, oxidants that are generated by activated PMN, we reasoned that Msr-deficient bacteria would be more vulnerable to PMN killing. We fed opsonized wild-type, $\triangle m s r A 1 B$ and complemented mutants to PMN for $10 \mathrm{~min}$ to allow maximum ingestion. Subsequently, extracellular bacteria were removed and the fate of ingested $S$. aureus assessed immediately (time 0 ) and after 30 and $60 \mathrm{~min}$ (fig. 2d). Because PMN begin to kill bacteria soon after the ingestion of bacteria and during the $10 \mathrm{~min}$ that are allowed for phagocytosis to occur (data not shown), we measured in parallel the viability of bacteria fed to DPItreated PMN. The pharmacological inhibition of the NADPH oxidase by DPI [22] ensured that minimal killing of bacteria was achieved by time 0 , thus providing us with the total number of ingested bacteria at the start of the time course. To quantitate PMN killing of ingested S. aureus over time, we enumerated viable bacteria recovered from normal PMN at each time point relative to the number of bacteria that was recovered at time 0 from the same strain fed to DPI-treated PMN. There was a reduction in the viability of all strains over time, but viable bacteria persisted even $1 \mathrm{~h}$ after ingestion. The $\triangle m s r A 1 B \mathrm{mu}$ tant was more susceptible to PMN killing than was the wild-type mutant at 30 and $60 \mathrm{~min}(\mathrm{p}<0.05)$.

Together, these data indicate that $m s r A 1 B$ contributed to the recovery of bacteria, not only after exposure to oxidants in isolation but also in the more complicated context of the PMN phagosome, where oxidants and granule proteins synergize to damage ingested targets.

\section{msrA1 Induction in S. aureus Exposed to PMN}

To examine the expression of $m s r$ in PMN-ingested bacteria, we recovered $S$. aureus from PMN that had been fed bacteria. After $10 \mathrm{~min}$ of phagocytosis by PMN, extracellular bacteria were aspirated away and the time course initiated. At time 0 , the level of $m s r A l$ in the ingested bacteria was higher in organisms grown to the stationary phase relative to those grown to the mid-log phase (fig. 3a, b), with levels in both increasing further at $15 \mathrm{~min}$ and 


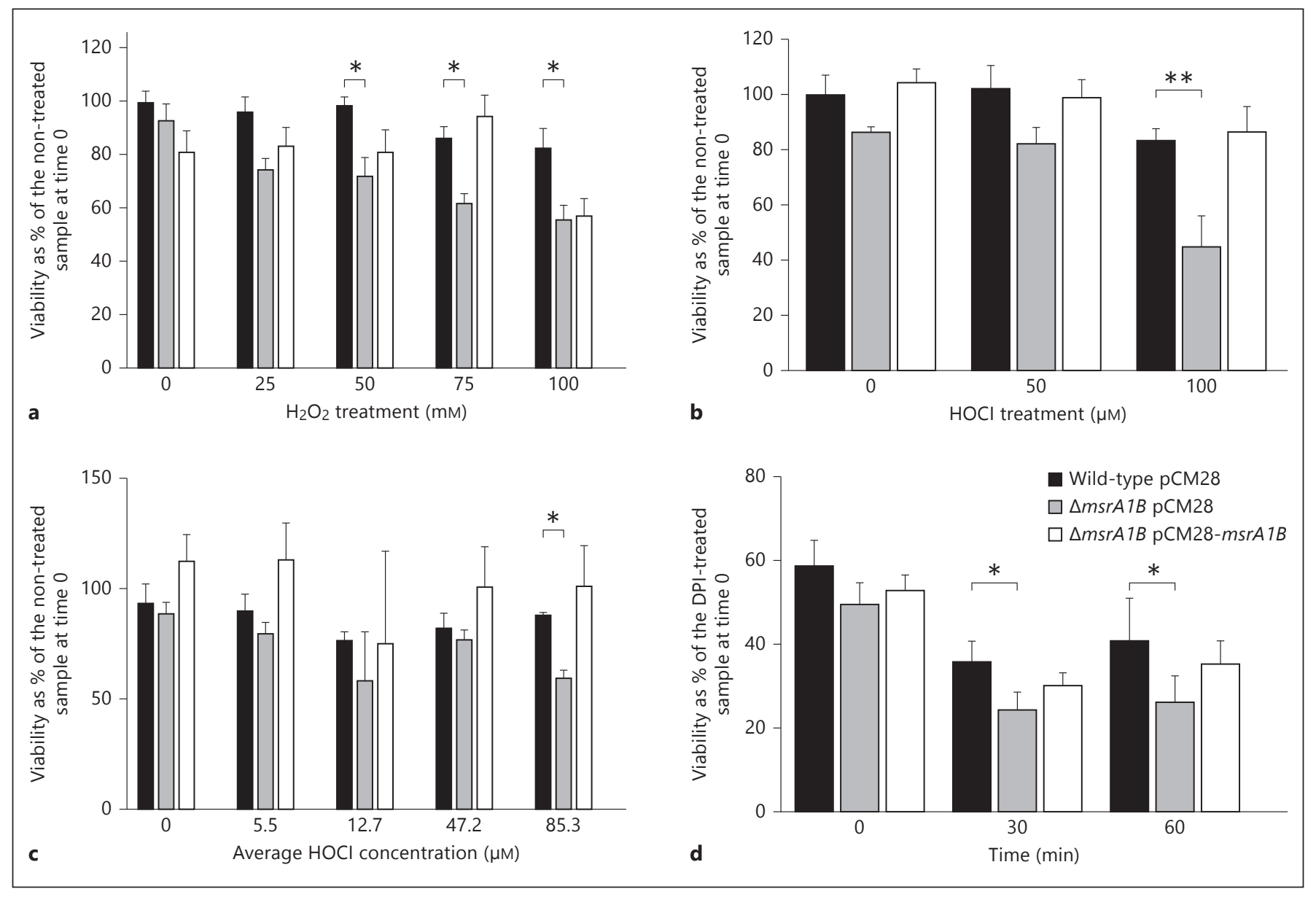

Fig. 2. Susceptibility of wild-type and $m s r$ mutants to oxidants and PMN. Wild-type, $\triangle m s r A 1 B$ and complemented $\triangle m s r A 1 B$ strains were grown to the mid-log phase, resuspended in $\mathrm{PBS}$ and treated with $\mathrm{H}_{2} \mathrm{O}_{2}(\mathbf{a}), \mathrm{HOCl}$ (b) or $\mathrm{HOCl}$ generated by the $\mathrm{MPO}-\mathrm{H}_{2} \mathrm{O}_{2}$ system (c) at the stated concentrations for $1 \mathrm{~h}$. After $1 \mathrm{~h}$ at $37^{\circ} \mathrm{C}$, the bacteria were plated and CFU enumerated after overnight growth. Data represent $\mathrm{CFU} / \mathrm{ml}$ as a percentage of non-treated control for each strain at time 0 . Data are the mean \pm SEM $(n=6$ experiments for $\mathbf{a}$ and $\mathbf{b}$, and $\mathrm{n}=3$ experiments for $\mathbf{c}$ ). At each concentration of the oxidant, a paired t test was used to compare

remaining high at 30 and $60 \mathrm{~min}$. Incubation in the absence of PMN did not promote the expression of msrA1.

Given that Msr participates in cellular oxidant defense, we sought to determine whether oxidants generated within PMN phagosomes could drive msrAl expression in ingested $S$. aureus. To that end, we compared msrAl expression in S. aureus fed to normal PMN, PMN pretreated with DPI and PMN isolated from individuals with CGD, thereby providing $\mathrm{PMN}$ with pharmacologic or genetic absence of a functional phagocyte NADPH oxidase as a source of reactive oxygen species [23]. We detected high levels of the wild-type and $\triangle m s r A 1 B$ strains $\left({ }^{*} \mathrm{p}<0.05,{ }^{* *} \mathrm{p}<0.01\right)$. d Each bacterial strain was opsonized in pooled human serum and then fed to normal or DPI-treated PMN (MOI of 5:1). Ingested bacteria were recovered at the indicated time points and CFU were enumerated. At each time point, the viability of a strain is expressed as bacteria recovered from normal PMN as a percent of the same strain recovered from DPI-treated PMN at time 0 . A paired t test was used to compare the wild-type and $\triangle m s r A 1 B$ strains at each time point $\left({ }^{*} \mathrm{p}<0.05\right)$. Data represent the mean \pm SEM $(\mathrm{n}=6 \mathrm{ex}-$ periments). 


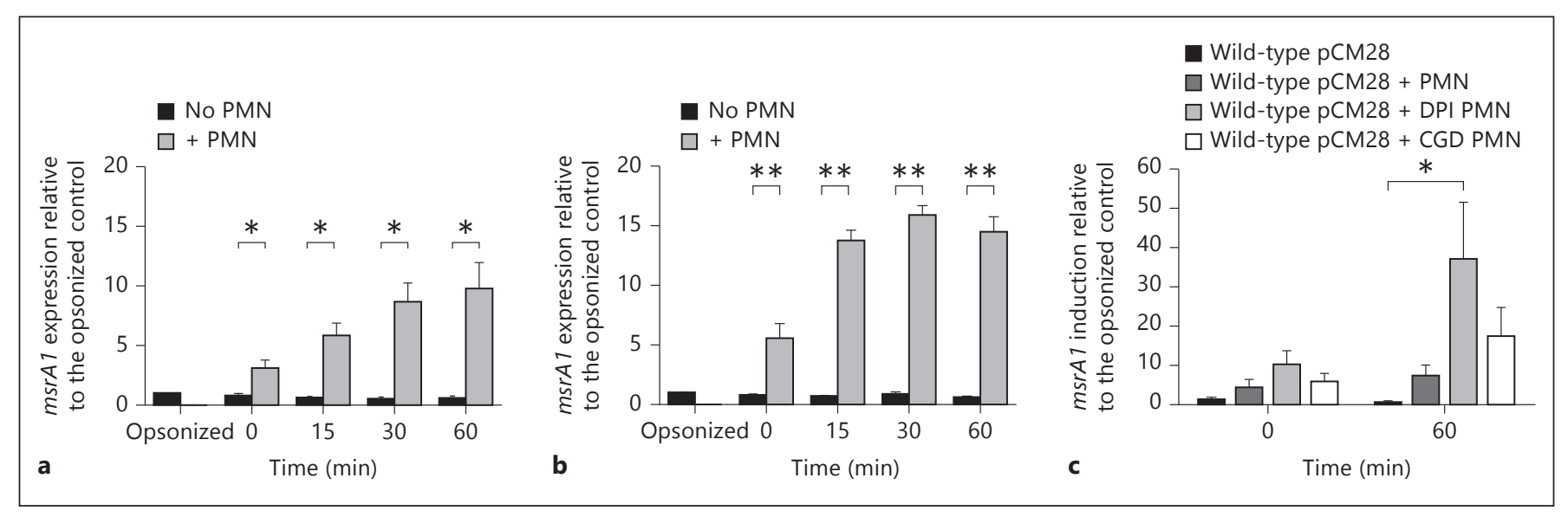

Fig. 3. $m s r A 1$ expression in wild-type mutant ingested by normal and oxidase-deficient PMN. Serum-opsonized wild-type $S$. aureus in the mid-log (a) and stationary phase (b) were incubated alone or fed to PMN at an MOI of 1:1. At 0, 15, 30 and 60 min after phagocytosis, both ingested bacteria had recovered from PMN and bacteria incubated alone were prepared for real-time PCR. The expression of $m s r A 1$ was normalized to the expression of gapdh, and fold change in gene expression was relative to that in opsonized S. aureus prior to exposure to PMN. Data represent the mean \pm SEM ( $n=3$ experiments). At each time point, a paired $t$ test was used to analyze the difference between the ingested and non-ingested bacteria $\left({ }^{*} \mathrm{p}<0.05,{ }^{* *} \mathrm{p}<0.01\right)$. c Opsonized mid$\log$ phase wild-type $S$. aureus was incubated alone or fed at an MOI of 1:1 to suspended normal PMN, DPI-treated PMN or PMN derived from 1 of 4 unrelated individuals with X-linked CGD. Data represent the mean \pm SEM ( $n=4$ experiments). Data after 60 min were analyzed by 1 -way ANOVA followed by a Tukey post-test $(* \mathrm{p}<0.05)$. media with vancomycin to induce $m s r A 1$ expression in the presence or absence of $\mathrm{H}_{2} \mathrm{O}_{2}$ or $\mathrm{HOCl}$. Since $\mathrm{HOCl}$ is such a potent antimicrobial agent [1], much lower concentrations of $\mathrm{HOCl}(10$ and $30 \mu \mathrm{M})$ were used relative to $\mathrm{H}_{2} \mathrm{O}_{2}(100 \mathrm{mM})$. At the tested concentrations, neither oxidant induced $m s r A 1$ expression when used alone, but vancomycin alone induced msrA1 more than 15-fold (fig. 4). In the presence of 10 or $30 \mu \mathrm{M}$ of $\mathrm{HOCl}$, the level of $m s r A 1$ induced by vancomycin was similar to that observed with vancomycin treatment alone. However, in the presence of $100 \mathrm{mM} \mathrm{H}_{2} \mathrm{O}_{2}$, the effect of vancomycin on msrA1 induction was markedly reduced (fig. 4). These data suggest that although oxidants did not directly induce $m s r A 1$, exposure to $\mathrm{H}_{2} \mathrm{O}_{2}$ but not to $\mathrm{HOCl}$ may limit the $m s r A 1$ response to stimuli arising from disruption of the bacterial cell wall. The observed decrease in vancomycin-induced $m s r A 1$ response in the presence of $\mathrm{H}_{2} \mathrm{O}_{2}$ did not reflect a global inhibition of transcription by oxidant treatment, as the expression of the $\mathrm{H}_{2} \mathrm{O}_{2}$-responsive gene alkyl hydroperoxide reductase was increased as expected [24] (online suppl. fig. 2).

\section{Modulation of msrA1 by Staphylococcal TCS}

We sought to determine which pathways in $S$. aureus participate in the detection and relay of signals that modulate the induction of $m s r A 1$. To sense and respond to the

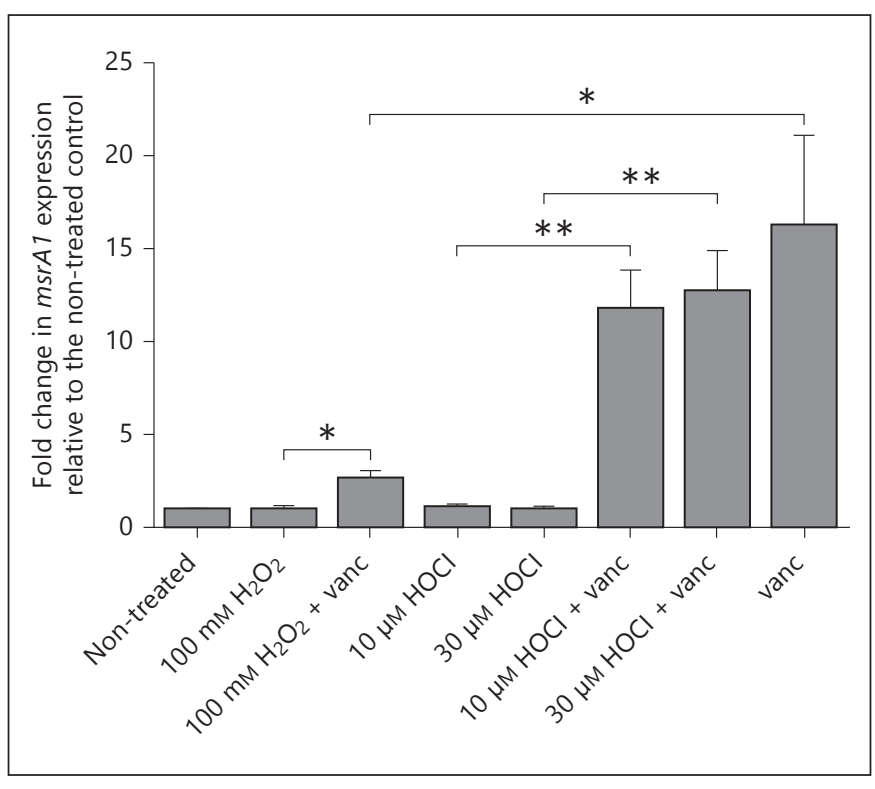

Fig. 4. $m s r A 1$ expression in $S$. aureus treated with oxidants and vancomycin (vanc). Wild-type $S$. aureus cultured in minimal media was treated with $\mathrm{H}_{2} \mathrm{O}_{2}$ or $\mathrm{HOCl}$ in the presence or absence of vancomycin $(7 \mu \mathrm{g} / \mathrm{ml})$ or with vancomycin alone for $1 \mathrm{~h}$ at $37^{\circ} \mathrm{C}$. Bacteria were then assessed for $m s r A 1$ expression by real-time PCR and the data were normalized to gapdh expression. The data represent the fold change in $m s r A 1$ expression relative to the nontreated control (mean \pm SEM, $n=6$ ). A paired $t$ test was used to compare sample conditions $\left(* \mathrm{p}<0.05,{ }^{* *} \mathrm{p}<0.01\right)$. 
Fig. 5. Regulation of $m s r A 1$ by TCS. a Wildtype and mutant strains of $S$. aureus that were each deficient in one TCS were grown to the mid-log phase and treated with vancomycin for $1 \mathrm{~h}$ (table 1 ). TCS mutants are labeled in the graph with the gene locus or TCS name where known. The expression of msrA1 measured by real-time PCR was normalized to the expression of gapdh. Fold change in $m s r A 1$ is expressed relative to the untreated wild-type strain. The data represent the mean of two independent experiments. b Wild-type and $\Delta v r a S R$ grown to the stationary phase were diluted to an $\mathrm{OD}_{550}$ of 0.3 and then treated with buffer or with D-cycloserine. Msr activity in bacterial lysates was measured. Data shown represent the mean \pm SEM $(n=4)$. A paired $t$ test was performed between the cycloserine-treated wild-type and mutant samples (* $\mathrm{p}<0.05)$. c Serum-opsonized wild-type, $\triangle v r a S R$ and complemented $\triangle v r a S R$ grown to the mid-log phase were fed to PMN (MOI of 1:1), and $m s r A 1$ expression in the ingested bacteria was measured and normalized to gapdh expression. Fold change is expressed relative to opsonized wild-type bacteria at time 0 . Data represent the mean \pm SEM $(n=9)$ and are analyzed by 1-way ANOVA with a Tukey post-test $\left({ }^{*} \mathrm{p}<0.05,{ }^{* * *} \mathrm{p}<0.001\right)$.
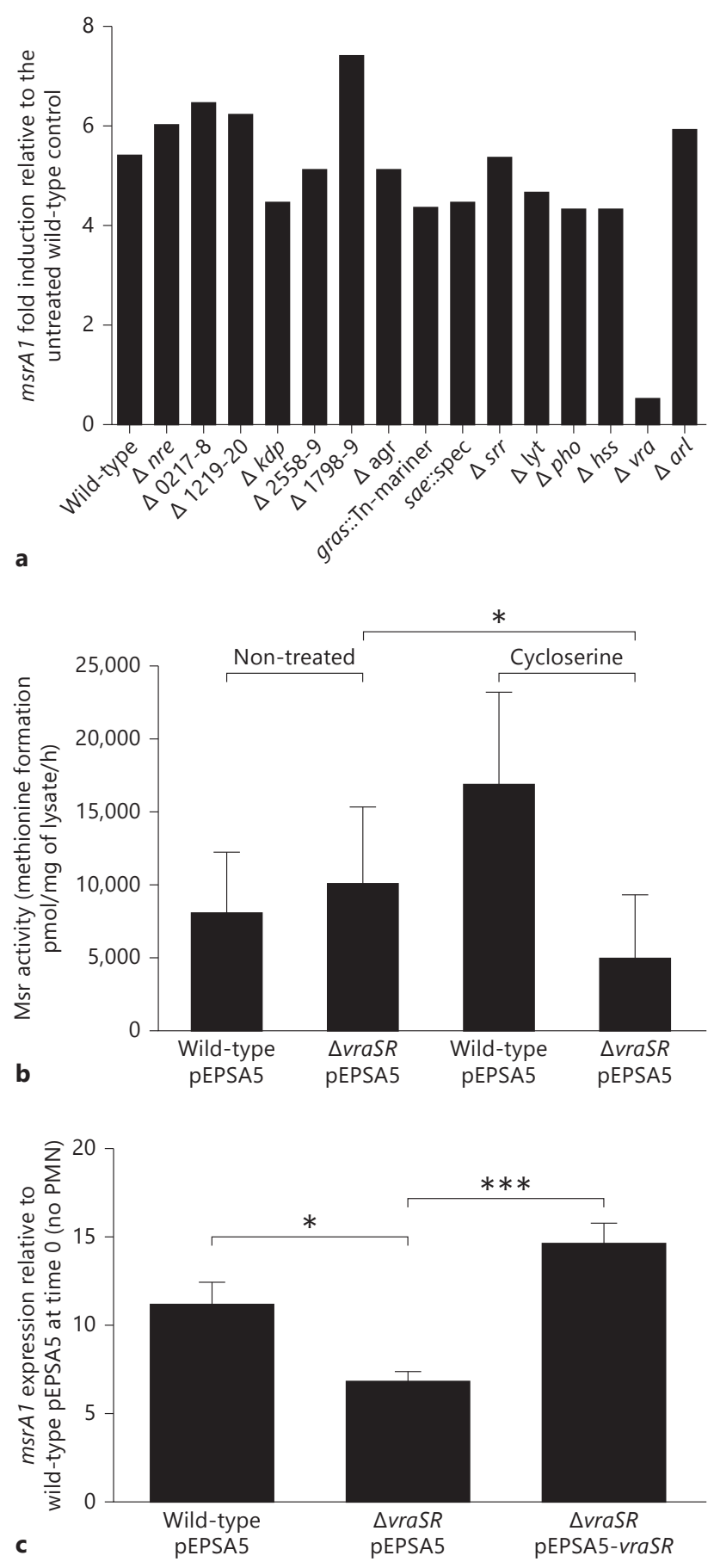

environment, prokaryotes utilize TCS [25], which typically consist of a cell surface histidine kinase as sensor and a cytoplasmic regulator to coordinate a transcriptional response. Only a few of the 16 TCS encoded in the $S$. aureus genome have been thoroughly characterized.
In a screen of a library of 15 nonessential TCS mutants for impaired $m s r A 1$ induction in response to vancomycin, deletion of $v \mathrm{raSR}$ resulted in loss of $m s r A 1$ induction under our experimental conditions (fig. 5a). To confirm the observed relationship between VraSR and 
Msr, we quantitated Msr activity in the vraSR deletion mutant $(\triangle v r a S R)$ and its isogenic wild-type mutant after treatment with a cell wall-active antibiotic structurally unrelated to vancomycin. We chose D-cycloserine for its ability to induce $m s r A 1$ and, more importantly, because its antistaphylococcal activity, in contrast to that of vancomycin, is unchanged in the absence of a functional VraSR system $[26,27]$. At a concentration of D-cycloserine that modulated Msr activity with the least impact on viability (data not shown), D-cycloserine-treated wild-type mutants showed approximately 2 -fold more Msr activity than did the non-treated controls. In contrast, treatment of $\Delta v \mathrm{raSR}$ resulted in less Msr activity relative to the treated wild-type strain $(\mathrm{p}<0.05$; fig. $5 b$ ). These data suggested that VraSR contributed to the regulation of $m s r A 1$ in response to cell wall-active antibiotics.

To determine whether VraSR participated in the regulation of $m s r A 1$ in PMN-ingested bacteria, we measured $m s r A 1$ expression in wild-type, $\Delta v r a S R$ and $\triangle v r a S R$ mutants complemented with a multicopy plasmid $(\Delta v r a S R$ with pEPSA5-vraSR) after phagocytosis by PMN. Phagocytosis of $S$. aureus by PMN was the same for all the strains (data not shown). Both wild-type and complemented mutants significantly upregulated $m s r A 1$ in response to ingestion by approximately 11 - and 15-fold, respectively. In contrast, $\Delta v r a S R$ exhibited a relatively muted response, with only an approximately 7 -fold induction in $\mathrm{msrA1}$ ( $\mathrm{p}<0.05$; fig. $5 \mathrm{c}$ ). Similar to the trend observed in $m s r A 1$, vraS expression in $S$. aureus ingested by DPI-treated PMN and CGD PMN was higher than that in normal PMN (online suppl. fig. 3). Taken together, these data provide support for a link between VraSR, a TCS that can be activated by perturbations to the cell wall, and Msr, one of the oxidant repair systems. However, they also highlight the complexity of $m s r A 1$ regulation in a biological setting composed of multiple interacting antimicrobial toxins, as occurs in PMN phagosomes, and implicate factors other than VraSR.

\section{PMN Granules Induce the Expression of msrA1}

Optimal PMN antimicrobial action relies not only on oxidants from the NADPH oxidase but also on granule proteins released into phagosomes during degranulation [28]. Granule proteases (e.g., elastase, cathepsin G) [29-31] and cationic antimicrobial proteins (e.g., defensins and cathelicidins) [32] can compromise the stability of bacterial membranes that in turn may disrupt the cell wall [33-35]. Because our data demonstrate that upregulation of $m s r A 1$ in ingested $S$. aureus could be medi-

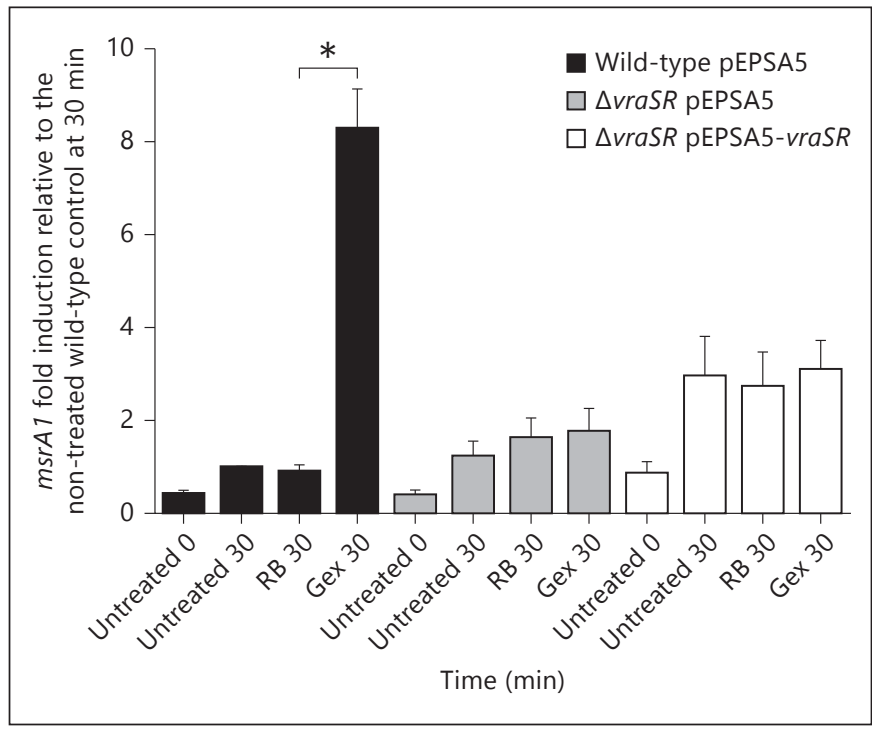

Fig. 6. $m s r A 1$ expression in $S$. aureus treated with PMN granule proteins. Wild-type, $\triangle v r a S R$ and complemented $\triangle v r a S R$ strains were treated with PMN granule extracts (Gex), PBS (negative control) or RB (vehicle control). The levels of $m s r A 1$ in the samples at 0 and 30 min were assessed by real-time PCR. The expression levels were normalized to the expression of $g a p d h$. Data represent the mean \pm SEM ( $n=3$ experiments). To compare the $\mathrm{RB}$ sample with the Gex sample at $30 \mathrm{~min}$, a paired t test was used for each strain $(* \mathrm{p}<0.05)$.

ated by factors other than PMN-derived oxidants (fig. 3c) and could be induced by cell wall stress, we hypothesized that granule proteins could trigger a response that was relayed through V raSR. To test this hypothesis, we measured msrAl in bacteria exposed to PMN granule-rich extracts in the absence of exogenous reactive oxygen species. The level of $m s r A 1$ expression was lowest at the start of the experiment prior to any treatment in all the strains. After a 30-min incubation period, $m s r A 1$ expression was slightly higher in bacteria that were not treated or in the RB control. This increase in $m s r A 1$ expression may reflect changes in the growth status of the bacteria, since $m s r A 1$ expression varies during different growth phases [3]. In bacteria treated with granule extract, msrAl expression was significantly higher in the wild-type when compared to the RB-treated bacteria at $30 \mathrm{~min}(\mathrm{p}<0.05$; fig. 6$)$. In contrast, the level of msrA1 in granule extract-treated samples in $\triangle v r a S R$ was not significantly elevated compared to its $\mathrm{RB}$ control. These data suggest that granule proteins alone promoted increased msrAl expression and that VraSR contributed to the modulation of $m s r A 1$ in response to granule proteins. 


\section{Discussion}

Optimal antimicrobial action in PMN relies heavily on phagocyte-generated oxidants. In such an inhospitable environment, ingested $S$. aureus rapidly initiates a program of transcriptional responses that promote its survival and dissemination $[11,36]$, making it likely that the net balance between sustained damage and repair dictates the fate of ingested bacteria. Defensive strategies employed by bacteria in response to oxidants involve both genes encoding proteins that target oxidants, such as catalase, superoxide dismutase, thioredoxin, and alkyl hydroperoxide reductase [36], as well as those that repair oxidant-mediated damage and restore normal function. Msr are key enzymes in the defense against damage mediated by reactive oxygen species that are produced as a byproduct of aerobic respiration, and their evolutionary conservation across nearly all species underscores their importance $[37,38]$. $\mathrm{HOCl}$ oxidizes protein methionines in Escherichia coli in a dose-dependent fashion, and methionine oxidation closely correlates with loss of bacterial viability [39]. Conversely, the capacity of Msr to repair damaged methionines parallels the increased resistance of E. coli to killing by $\mathrm{HOCl}[39]$ and likewise contributes to the defenses of Mycobacterium tuberculosis [40] and Helicobacter pylori against $\mathrm{HOCl}$ [41]. Thus, we reasoned that oxidation of key proteins in S. aureus may also result in reduced viability when the Msr-mediated repair system is inadequate to meet demands.

We demonstrate that the absence of Msr activity increased the susceptibility of $S$. aureus to the oxidants $\mathrm{H}_{2} \mathrm{O}_{2}$ and $\mathrm{HOCl}$. We found that the ability of the Msr system to temper the effects of oxidant damage was less marked when $S$. aureus was treated with low doses of $\mathrm{H}_{2} \mathrm{O}_{2}$ or $\mathrm{HOCl}$, which may indicate that the role of $\mathrm{Msr}$ in oxidant defense becomes more important when $S$. aureus is subjected to higher levels of oxidant stress and greater levels of protein damage (fig. $2 b$ ). In addition, we observed that even in the absence of any oxidant treatment, the percentage of recovered $\triangle m s r A 1 B$ was sometimes slightly lower than that of the wild-type and complemented strain (fig. 2a-c). Although this difference did not reach statistical significance, it suggested that $\triangle m s r A 1 B$ may be slightly more sensitive to the aerobic environment during the 1-hour incubation in PBS than the other strains. This behavior contrasts with our observation that all the strains showed similar growth in TSB. Since TSB is a rich source of substrates that could serve as oxidant sinks, it is likely that the enriched media both promotes microbial growth directly and neutralizes some of the environmental oxidants, thus limiting their deleterious effects on the bacteria.

The absence of Msr activity increased the susceptibility of $S$. aureus not only to reagent $\mathrm{H}_{2} \mathrm{O}_{2}$ and $\mathrm{HOCl}$ but also to the antimicrobial effects of PMN. In contrast to the immediate exposure to high concentrations of oxidants imposed by adding $\mathrm{H}_{2} \mathrm{O}_{2}$ or $\mathrm{HOCl}$ to suspensions of $S$. aureus, oxidant generation within phagosomes occurs gradually, following the kinetics of NADPH oxidase assembly and activation. As a result, oxidants within PMN may be generated sufficiently slowly to allow reparative responses such as the induction of $m s r$ to be engaged. Given the role of Msr in oxidant repair, we speculated that PMN-derived oxidants may drive the upregulation of $m s r A 1$ that we observed in S. aureus ingested by PMN. Our data show that bacteria ingested by normal PMN upregulated $m s r A 1$ rapidly after phagocytosis. S. aureus ingested by PMN that have impaired NADPH oxidase activity and were not exposed to phagosomal oxidants also upregulated $m s r A 1$ after phagocytosis and to higher levels. These data suggest that the $m s r A 1$ response to ingested $S$. aureus may be muted by the presence of oxidants in the phagosome, either directly by oxidant attack on bacteria or indirectly by oxidative modifications of the hostderived phagosomal contents. In the absence of PMN, S. aureus exposed simultaneously to $\mathrm{H}_{2} \mathrm{O}_{2}$ and a cell wallactive antibiotic (vancomycin) had a blunted $m s r A 1$ transcriptional response relative to that seen in vancomycin alone. Unexpectedly, $\mathrm{HOCl}$, a much more powerful oxidant than $\mathrm{H}_{2} \mathrm{O}_{2}$, did not influence vancomycin-induced msrA1. The mechanistic basis for the differential responses to the two oxidants is unknown and merits further study. These findings illustrate how oxidants and granule proteins present in phagosomes can act synergistically on target bacteria.

The $S$. aureus genome encodes three other $m s r$ genes besides $m s r A 1$, including $m s r B, m s r A 2$ and $m s r A 3$. Since $m s r B$ is cotranscribed and regulated by the same promoter, the pattern of expression follows that of $m s r A 1$ and it is responsive to the same stimuli. The other two $m s r$ genes are located at different genomic loci and under the regulation of promoters that are responsive to differing stresses than that of $m s r A 1$ and $m s r B$. Not only do $m s r A 2$ and $m s r A 3$ show a different pattern of expression to $m s r A 1$ and $m s r B$ during varied phases of growth, they also do not respond to the same stress signals [3]. For these reasons and also because MsrA 1 and MsrB account for almost all the Msr activity in S. aureus (fig. 1), the expression of $m s r A 2$ and $m s r A 3$ was not evaluated in this study. 
The regulation of $m s r A 1$ in $S$. aureus is not yet fully elucidated, although $m s r$ is one of a set of genes known as the cell wall stress stimulon, which is regulated by stresses inflicted by cell wall-active antibiotics such as $\beta$-lactams, vancomycin and D-cycloserine [42]. Genes in the cell wall stress stimulon overlap with those regulated by VraSR, a TCS that influences susceptibility of $S$. aureus to vancomycin by modulating cell wall biosynthesis [26]. The VraSR system senses disruptions of cell wall biosynthesis in target bacteria, which may explain why both cell wallactive antibiotics and antimicrobial peptides induce the VraSR system [43]. In our study, PMN granule proteins alone stimulated $m s r$ expression in a VraSR-dependent fashion. The mechanism by which VraSR is activated and how it subsequently modulates $m s r A 1$ remain to be elucidated, including whether VraR directly or indirectly regulates $m s r$. We noted that the introduction of the complementation plasmid into $\triangle v r a S R$ increased $m s r A 1$ expression to higher levels than that observed in $\triangle v r a S R$ both in the presence and absence of granule extracts but did not restore it to wild-type levels. The levels of $m s r A 1$ were also similar in the RB and granule extract-treated samples for this strain. Complementation of a mutation can be challenging and, given that the restoration of $v \mathrm{raSR}$ expression was driven from a multicopy plasmid and from an inducible promoter rather than from its native promoter, the gene dosage and regulation of $v r a S R$ may not accurately emulate the wild-type strain under these conditions. Nonetheless, the levels of vraSR in $\triangle v r a S R$ with pEPSA5-vraSR were higher than in $\triangle v r a S R$ and allowed for greater $m s r A 1$ expression.

The transcriptional changes that occur in phagocytosed bacteria reflect a coordinated response to the multitude of stresses experienced within the host environment. Given the complexity of this environment, multiple signaling pathways underpin the net global response, and their cross-talk can contribute to the modulation of stress response genes such as $m s r$. Indeed, our data show that there are factors other than VraSR that can modulate the expression of $m s r A 1$ in $S$. aureus within the PMN environment. The identification and characterization of signaling systems in addition to VraSR in the regulation of msrA1 modulation remain an area of interest.

Our study highlights Msr as one of the mechanisms by which S. aureus may resist the consequences of the multifaceted antimicrobial attack that occurs in PMN phagosomes and reemphasizes that the relationships between stress and repair pathways are not necessarily straightforward. We speculate that Msr and functionally related proteins in the antioxidant pathway serve important roles in cell wall biosynthesis and homeostasis. Further understanding of the relationship between oxidant stress, both exogenous and endogenous, and cell wall damage in the context of elucidating how $S$. aureus survives within PMN may provide insights into the pathogenesis of staphylococcal disease and into the development of novel therapeutic approaches.

\section{Acknowledgements}

The authors express special thanks to the members of the Nauseef and Horswill laboratories for their help in this project. This work was supported by National Institutes of Health grants R01 AI078921 and R01 AI07958 to A.R.H. and W.M.N., respectively, and by a Merit Review Grant (to W.M.N.) from the Department of Veterans Affairs, Veterans Health Administration, Office of Research and Development, with facilities and resources of the Veterans Administration in Iowa City, Iowa, USA.

\section{Disclosure Statement}

None of the authors have conflicts of interests.

\section{References}

1 Klebanoff SJ, Kettle AJ, Rosen H, Winterbourn CC, Nauseef WM: Myeloperoxidase: a front-line defender against phagocytosed $\mathrm{mi}-$ croorganisms. J Leukoc Biol 2013;93:185-198.

2 Vogt W: Oxidation of methionyl residues in proteins: tools, targets, and reversal. Free Radic Biol Med 1995; 18:93-105.

> Singh K, Singh VK: Expression of four methionine sulfoxide reductases in Staphylococcus aureus. Int J Microbiol 2012;2012:719594.

-4 Singh VK, Moskovitz J, Wilkinson BJ, Jayaswal RK: Molecular characterization of a chromosomal locus in Staphylococcus aureus that contributes to oxidative defence and is highly induced by the cell-wall-active antibiotic oxacillin. Microbiology 2001;147:3037-3045.

5 Singh VK, Moskovitz J: Multiple methionine sulfoxide reductase genes in Staphylococcus aureus: expression of activity and roles in tolerance of oxidative stress. Microbiology 2003; 149:2739-2747.

6 Luo S, Levine RL: Methionine in proteins defends against oxidative stress. FASEB J 2009; 23:464-472.

-7 Boles BR, Thoendel M, Roth AJ, Horswill AR: Identification of genes involved in polysac- charide-independent Staphylococcus aureus biofilm formation. PLoS One 2010;5:e10146.

8 Kiedrowski MR, Kavanaugh JS, Malone CL, Mootz JM, Voyich JM, Smeltzer MS, Bayles KW, Horswill AR: Nuclease modulates biofilm formation in community-associated methicillin-resistant Staphylococcus aureus. PLoS One 2011;6:e26714.

>9 Nygaard TK, Pallister KB, Ruzevich P, Griffith S, Vuong C, Voyich JM: SaeR binds a consensus sequence within virulence gene promoters to advance USA300 pathogenesis. J Infect Dis 2010;201:241-254.
Methionine Sulfoxide Reductases in

S. aureus
J Innate Immun 2014;6:353-364 DOI: $10.1159 / 000355915$ 
10 Bose JL, Fey PD, Bayles KW: Genetic tools to enhance the study of gene function and regulation in Staphylococcus aureus. Appl Environ Microbiol 2013;79:2218-2224.

-11 Pang YY, Schwartz J, Thoendel M, Ackermann LW, Horswill AR, Nauseef WM: agrdependent interactions of Staphylococcus aureus USA300 with human polymorphonuclear neutrophils. J Innate Immun 2010;2 546-559.

$>12$ Forsyth RA, Haselbeck RJ, Ohlsen KL, Yamamoto RT, Xu H, Trawick JD, Wall D, Wang L, Brown-Driver V, Froelich JM, KG C, King P, McCarthy M, Malone C, Misiner B, Robbins D, Tan Z, Zhu Zy ZY, Carr G, Mosca DA, Zamudio C, Foulkes JG, Zyskind JW: A genomewide strategy for the identification of essential genes in Staphylococcus aureus. Mol Microbiol 2002;43:1387-1400.

$\checkmark 13$ Kreiswirth BN, Lofdahl S, Betley MJ, O’Reilly M, Schlievert PM, Bergdoll MS, Novick RP: The toxic shock syndrome exotoxin structural gene is not detectably transmitted by a prophage. Nature 1983;305:709-712.

14 Novick RP: Genetic systems in staphylococci. Methods Enzymol 1991;204:587-636.

15 Nauseef WM: Isolation of human neutrophils from venous blood. Methods Mol Biol 2007; 412:15-20.

-16 Dypbukt JM, Bishop C, Brooks WM, Thong B, Eriksson H, Kettle AJ: A sensitive and selective assay for chloramine production by myeloperoxidase. Free Radic Biol Med 2005;39: 1468-1477.

17 Singh VK, Jayaswal RK, Wilkinson BJ: Cell wall-active antibiotic induced proteins of Staphylococcus aureus identified using a proteomic approach. FEMS Microbiol Lett 2001; 199:79-84.

18 DeRusso PA, Philpott CC, Iwai K, Mostowski HS, Klausner RD, Rouault TA: Expression of a constitutive mutant of iron regulatory protein 1 abolishes iron homeostasis in mammalian cells. J Biol Chem 1995;270:15451-15454.

19 Saleem A, Yuan ZM, Taneja N, Rubin E, Kufe DW, Kharbanda SM: Activation of serine/ threonine protein kinases and early growth response 1 gene expression by tumor necrosis factor in human myeloid leukemia cells. J Immunol 1995; 154:4150-4156.

20 Chapman AL, Hampton MB, Senthilmohan R, Winterbourn CC, Kettle AJ: Chlorination of bacterial and neutrophil proteins during phagocytosis and killing of Staphylococcus aureus. J Biol Chem 2002;277:9757-9762.
21 Winterbourn CC, Hampton MB, Livesey JH, Kettle AJ: Modeling the reactions of superoxide and myeloperoxidase in the neutrophil phagosome: implications for microbial killing. J Biol Chem 2006;281:39860-39869.

22 Cross AR, Jones OT: The effect of the inhibitor diphenylene iodonium on the superoxidegenerating system of neutrophils. Specific labelling of a component polypeptide of the oxidase. Biochem J 1986;237:111-116.

23 Baehner RL, Nathan DG: Leukocyte oxidase: defective activity in chronic granulomatous disease. Science 1967;155:835-836.

24 Cosgrove K, Coutts G, Jonsson IM, Tarkowski A, Kokai-Kun JF, Mond JJ, Foster SJ: Catalase (KatA) and alkyl hydroperoxide reductase (AhpC) have compensatory roles in peroxide stress resistance and are required for survival, persistence, and nasal colonization in Staphylococcus aureus. J Bacteriol 2007; 189:1025-1035.

25 Mizuno T: His-Asp phosphotransfer signal transduction. J Biochem 1998;123:555-563.

26 Kuroda M, Kuroda H, Oshima T, Takeuchi F, Mori H, Hiramatsu K: Two-component system VraSR positively modulates the regulation of cell-wall biosynthesis pathway in Staphylococcus aureus. Mol Microbiol 2003; 49:807-821.

27 Dengler V, Meier PS, Heusser R, Berger-Bachi B, McCallum N: Induction kinetics of the Staphylococcus aureus cell wall stress stimulon in response to different cell wall active antibiotics. BMC Microbiol 2011;11:16.

Hager M, Cowland JB, Borregaard N: Neutrophil granules in health and disease. J Intern Med 2010;268:25-34.

29 Odeberg H, Olsson I: Antibacterial activity of cationic proteins from human granulocytes. J Clin Invest 1975;56:1118-1124.

30 Odeberg H, Olsson I: Microbicidal mechanisms of human granulocytes: synergistic effects of granulocyte elastase and myeloperoxidase or chymotrypsin-like cationic protein. Infect Immun 1976;14:1276-1283.

31 Thorne KJ, Oliver RC, Barrett AJ: Lysis and killing of bacteria by lysosomal proteinases. Infect Immun 1976;14:555-563.

32 Ganz T: Defensins: antimicrobial peptides of innate immunity. Nat Rev Immunol 2003;3: 710-720.
3 Brogden KA: Antimicrobial peptides: pore formers or metabolic inhibitors in bacteria? Nat Rev Microbiol 2005;3:238-250.

34 Belaaouaj A, Kim KS, Shapiro SD: Degradation of outer membrane protein A in Escherichia coli killing by neutrophil elastase. Science 2000;289:1185-1188.

35 Belaaouaj A: Neutrophil elastase-mediated killing of bacteria: lessons from targeted mutagenesis. Microbes Infect 2002;4:1259-1264.

36 Voyich JM, Braughton KR, Sturdevant DE, Whitney AR, Said-Salim B, Porcella SF, Long RD, Dorward DW, Gardner DJ, Kreiswirth $\mathrm{BN}$, Musser JM, DeLeo FR: Insights into mechanisms used by Staphylococcus aureus to avoid destruction by human neutrophils. J Immunol 2005;175:3907-3919.

37 Kryukov GV, Kumar RA, Koc A, Sun Z, Gladyshev VN: Selenoprotein R is a zinc-containing stereo-specific methionine sulfoxide reductase. Proc Natl Acad Sci USA 2002;99: 4245-4250

38 Tarrago L, Gladyshev VN: Recharging oxidative protein repair: catalysis by methionine sulfoxide reductases towards their amino acid, protein, and model substrates. Biochemistry (Mosc) 2012;77:1097-1107.

39 Rosen H, Klebanoff SJ, Wang Y, Brot N, Heinecke JW, Fu X: Methionine oxidation contributes to bacterial killing by the myeloperoxidase system of neutrophils. Proc Natl Acad Sci USA 2009; 106:18686-18691.

$>40$ Lee WL, Gold B, Darby C, Brot N, Jiang X, de Carvalho LP, Wellner D, St John G, Jacobs WR Jr, Nathan C: Mycobacterium tuberculosis expresses methionine sulphoxide reductases $A$ and $B$ that protect from killing by nitrite and hypochlorite. Mol Microbiol 2009;71: 583-593.

41 Mahawar M, Tran V, Sharp JS, Maier RJ: Synergistic roles of Helicobacter pylori methionine sulfoxide reductase and GroEL in repairing oxidant-damaged catalase. J Biol Chem 2011;286:19159-19169.

42 Pechous R, Ledala N, Wilkinson BJ, Jayaswal RK: Regulation of the expression of cell wall stress stimulon member gene $m s r A 1$ in methicillin-susceptible or -resistant Staphylococcus aureus. Antimicrob Agents Chemother 2004; 48:3057-3063.

43 Belcheva A, Golemi-Kotra D: A close-up view of the VraSR two-component system. A mediator of Staphylococcus aureus response to cell wall damage. J Biol Chem 2008;283: 12354-12364. 